\title{
Resiliensi pada Remaja yang Terinfeksi HIV/AIDS
}

Article History:

Received

23 November 2019

Review

27 November 2019

Revised

10 Desember 2019

\section{Accepted}

11 Desember 2019

Published

30 Desember 2019

\author{
Anna Dian Savitri ${ }^{1}$, Purwaningtyastuti ${ }^{1}$ \\ Fakultas Psikologi, Universitas Semarang \\ dsavie@usm.ac.id
}

\begin{abstract}
This study aims to determine the resilience picture of adolescents infected with HIV AIDS. Subjects in this study were adolescents who tested positive for HIV / AIDS, were undergoing ARV treatment and were willing to become research subjects. The informants who supported this research came from volunteers and the leadership of the shelter where the subjects resided. The method used in this research is a qualitative paradigm with a case study approach. Subject and informant data collection through structured interviews, while the analysis technique used uses triangulation of sources, by comparing the analysis of subject data with research informants. The results of this study are high levels of Sy resilience. Aspects of I Have include support and attention from others, Sy prioritizes pleasure and comfort, has a role model, has the drive to be independent, and has experienced health discrimination, gets good education and safety services. Factor I Am includes having an attractive attitude, expressing love through actions, and caring. I Can aspects include being able to express what is felt and thinking, being able to solve problems, being able to control emotions, and being able to foster good relations with others. The subject has good resilience and is able to accept his condition
\end{abstract}

Keywords: Resilience, Youth, HIV / AIDS

Abstrak. Penelitian ini bertujuan untuk mengetahui gambaran resiliensi remaja yang terinfeksi HIV AIDS . Subjek dalam penelitian ini adalah remaja yang positif terinfeksi HIV/AIDS, sedang menjalani pengobatan ARV dan bersedia menjadi subjek penelitian. Informan yang mendukung penelitian ini berasal dari relawan dan pimpinan rumah singgah tempat subjek bertempat tinggal. Metode yang digunakan dalam penelitian ini adalah paradigma kualitatif dengan pendekatan studi kasus. Pengumpulan data subjek dan informan melalui wawancara terstruktur, sedangkan teknik analisis yang digunakan menggunakan triangulasi sumber, dengan membandingkan analisis data subjek dengan informan penelitian. Hasil dari penelitian ini adalah tingkat resiliensi Sy tergolong tinggi. Aspek I Have meliputi dukungan dan perhatian dari orang lain, Sy mengutamakan kesenangan dan kenyamanan, mempunyai panutan, mempunyai dorongan untuk mandiri, dan pernah mengalami diskriminasi kesehatan, mendapat layanan pendidikan serta keamanan dengan baik. Faktor I Am meliputi mempunyai sikap yang menarik, mengungkapkan rasa sayang melalui perbuatan, serta peduli. Aspek I Can meliputi mampu mengungkapkan apa yang dirasakan dan pikirkan, mampu menyelesaikan masalah, mampu mengontrol emosi, dan mampu membina hubungan baik dengan orang lain. Subjek memiliki resiliensi yang baik dan sudah mampu menerima kondisi dirinya.

Kata kunci: Resiliensi, Remaja, HIV/AIDS 


\section{Pendahuluan}

Remaja sebagai generasi penerus bangsa memiliki banyak harapan dalam kehidupannya, terutama saat menginjak bangku Sekolah Menengah Atas. Desmita (2013:228) mengemukakan bahwa resiliensi (daya lentur) adalah kemampuan atau kapasitas insani yang dimiliki seseorang, kelompok atau masyarakat yang memungkinkannya untuk menghadapi, mencegah, meminimalkan dan bahkan menghilangkan dampak - dampak yang merugikan dari kondisikondisi yang tidak menyenangkan, atau bahkan mengubah kondisi-kondisi kehidupan yang menyenangkan menjadi suatu hal yang wajar untuk diatasi.

Teori dan penelitian terbaru menyimpulkan bahwa resiliensi muncul dari keajaiban sumber daya manusia yang luar biasa setiap hari. Selain itu resiliensi tidak hanya hasil dari orang yang berjuang mencapai sesuatu, juga bukan input berharga yang meningkatkan kesempatan untuk berhasil. Luthans (Kurniawan \& Noviza, 2018) menyebutkan bahwa resiliensi adalah perjalanan yang panjang, proses rumit dimana kompetensi dikembangkan setiap kali berinteraksi dengan lingkungan sehari-hari yang ditandai dengan perubahan dan ketidakpastian yang terus menerus.

HIV (Human Immuno Defeciency Syndrom) adalah virus yang menginfeksi manusia dengan menyerang sistem imun atau sistem kekebalan tubuh manusia sehingga tidak mampu melindungi diri dari serangan penyakit lain Menurut laporan WHO (World Health Organization) pada akhir 2009 sekitar 33.3 juta orang hidup dengan HIV. Pada tahun yang sama, sekitar 2,6 juta orang dengan kasus infeksi baru HIV, dan 1,8 juta meninggal karena AIDS termasuk 260.000 anak-anak. Dari semua ODHA, 68\% diantaranya berada di sub-sahara Afrika dimana terdapat sekitar 10,7juta orang membutuhkan ART (antiretroviral Teraphi)

Laporan monitoring VCT sampai juni 2011 menyebutkan jumlah kasus HIV positif di Indonesia kumulatif sebanyak 66.693 kasus. Secara kumulatif kasus HIV terbanyak dilaporkan dari Provinsi DKI Jakarta yaitu sebanyak 17.130 kasus, Jawa Timur sebanyak 8.469 kasus, Papua sebanyak 5.473 kasus, Jawa Barat sebanyak 4.974, Sumatera Utara sebanyak 4.382 kasus, Bali sebanyak 3.649 kasus, dan Jawa Tengah sebanyak 3.059 kasus (Kementrian Kesehatan, 2011), dari april sampai dengan Juni 2011 jumlah kasus AIDS yang baru dilaporkan adalah 2.001 kasus dari 59 kabupaten/ kota di 19 provinsi. Kasus AIDS terbanyak dilaporkan dari DKI Jakarta, Jawa Timur, Jawa Barat, Papua, Bali, Jawa Tengah, Kalimantan Barat, Sulawesi Selatan, DI Yogyakarta, dan Sulawesi Utara

Menurut Dinas Kesehatan Provinsi Sulawesi Selatan, kasus HIV\& Aids dari tahun 2005 hingga 20011 di provinsi Sulawesi Selatan yaitu 5.156 kasus. Sedangkan menurut Dinas Kesehatan Kota Makassar, jumlah kasus HIV\& AIDS di kota Makassar hingga September 2011 sebanyak 4.219 kasus. 
Berdasarkan data yang diperoleh dari petugas kesehatan Puskesmas Jumpandang Baru, hingga februari 2012 ODHA yang aktif mengikuti terapi ARV adalah 103 orang, yang terdiri dari 75 pria dan 28 wanita. Masalah yang timbul pada Orang Dengan HIV/ AIDS bukan hanya dari infeksi virus, ada juga dampak-dampak sosial yang terjadi misalnya dijauhi teman, keluarga, maupun dari masyarakat luas. Ketika individu dinyatakan terinfeksi HIV, sebagian besar menunjukkan perubahan karakter psikososial yaitu : hidup dalam stres, depresi, merasa kurangnya dukungan sosial, dan perubahan.

AIDS (acquired immunodeficiency syndrome) adalah sekumpulan gejala dan infeksi yang timbul karena rusaknya sistem kekebalan tubuh akibat infeksi virus HIV (human immunodeficiency virus). Virus tersebut mengakibatkan penurunan dan kerusakan sistem kekebalan tubuh, sehingga orang yang terinfeksi akan menjadi rentan terhadap berbagai macam penyakit. Penyakit ini menjadi pandemi di seluruh dunia. Hampir semua negara menyumbangkan angka kejadian penyakit HIV/AIDS (Kemenkes, 2013).

Direktorat Jenderal Pengendalian Penyakit dan Penyehatan Lingkungan Kementerian Kesehatan (Ditjen PP \& PL) melaporkan bahwa sejak tahun 1987 sampai dengan tahun 2013 penderita yang terinfeksi HIV sebanyak 127.416 penderita, kasus AIDS yang ditemukan sebanyak 52.348 penderita dan jumlah kematian akibat HIV/AIDS sebanyak 9.587 penderita. Dari banyak kasus yang ditemukan di Indonesia, kejadian tertinggi infeksi HIV terdapat di Provinsi DKIJakarta, yaitu sebanyak 28.790 penderita, sedangkan kasus AIDS tertinggi terdapat di Provinsi Papua, yaitu sebanyak 10.116 penderita (Kemenkes, 2013).

Provinsi Jawa Tengah menduduki peringkat ke-7 nasional setelah DKI Jakarta, Jawa Timur, Papua, Jawa Barat, Bali dan Sumatra Utara. Jumlah penderita HIV di Jawa Tengah yang ditemukan sampai dengan tahun 2013 sebanyak 6.963 penderita, sedangkan jumlah penderita AIDS sebanyak 1.042 penderita dengan jumlah kematian sebanyak 1.111 orang (Kemenkes, 2013).

Tingginya pertumbuhan HIVAIDS di Indonesia dipengaruhi oleh 3 hal, yaitu : meningkatnya pengguna narkoba suntik, maraknya seks bebas dan kelahiran bayi oleh ibu yang terinfeksi HIV (Kemenkes, 2013). Penyakit HIV/AIDS menimbulkan masalah yang cukup luas, baik pada orang yang terinfeksi HIV/AIDS (ODHA) maupun orang yang hidup dengan penderita HIV/AIDS (OHIDA).

Masalah yang muncul adalah masalah fisik, sosial dan emosional, Masalah fisik terjadi akibat dari penurunan daya tahan tubuh secara progresif yang mengakibatkan ODHA rentan terhadap berbagai macam penyakit terutama penyakit infeksi dan keganasan. Penyakit infeksi yang sering muncul pada penderita HIV/AIDS adalah tuberkulosis paru (TB paru), radang pada paru-paru (pneumonia), kelainan kulit berupa herpes simplex atau zoster, diare kronik dan infeksi pada hati (hepatitis). Penyakit keganasan di antaranya adalah kanker lapisan pembuluh 
darah limfatik (sarcoma kaposi), kanker sistem kekebalan tubuh (limfoma) (Nursalam dan Kurniawati, 2007). Masalah sosial dan emosional pada ODHA muncul akibat stigma negatif dari masyarakat. Stigma tersebut akhirnya mengakibatkan perlakuan diskriminatif terhadap mereka. Stigma dan diskriminasi terjadi karena adanya anggapan bahwa penyakit HIV/AIDS selalu berujung pada kematian. Penyakit ini sering diasosiasikan dengan perilaku atau kebiasaan buruk yang dianggap tidak sesuai dan bertentangandengan norma positif dalam masyarakat, persepsi masyarakat bahwa ODHA dengan sengaja menularkan penyakitnya, serta kurangnya pengetahuan yang benar tentang cara penularannya (Kemenkes, 2012).

Akibat stigma dan diskriminasi pada ODHA, akhirnya tidak semua ODHA mau membuka statusnya kepada orang lain. ODHA mau membuka statusnya kepada orang lain dengan berbagai pertimbangan, yaitu di antaranya untuk mengurangi beban yang dirasakan, untuk mendapatkan dukungan sosial maupun dukungan secara ekonomi serta sebagai wujud kepedulian terhadap masyarakat (Sukmandari, 2012). Hasil riset kesehatan dasar (Riskesdas) yang dilakukan oleh Kementrian Kesehatan tahun 2010, menemukan data bahwa sikap diskriminatif terhadap anggota keluarga yang terinfeksi HIV cukup tinggi. Sebanyak 21,7\% masih merahasiakan apabila ada anggota yang terinfeksi HIV/AIDS, dan terdapat 7,1\% penduduk yang bersifat mengucilkan ODHA (Kemenkes, 2010).

Dampak stigma dan diskriminasi secara sosial yang dialami ODHA berupa pengucilan, pengusiran, pemutusan hubungan kerja (PHK), kekerasan, kehilangan kesempatan akses pelayanan kesehatan, serta berkurangnya dukungan sosial. Sedangkan dampak stigma secara emosional yang paling sering ditemukan adalah masalah depresi.

Remaja yang terinfeksi HIV/AID atau disebut dengan ODHA (Orang Dengan HIV AIDS) apabila memiliki resiliensi maka akan terhindar dari berbagai resiko negatif yang mengganggu psikologisnya, setidaknya dapat kembali pulih dan dapat beradaptasi secara positif seperti remaja pada umumnya. Hal inilah yang dilakukan oleh Sy (18 th) , seorang remaja putri yang positif terinfeksi HIV AIDS, dalam wawancara yang dilakukan peneliti pada bulan Desember 2017, Sy menceritakan bahwa saat mendengar vonis bahwa dirinya positif terinfeksi HIV/AIDS kondisi psikologisnya sangat terpukul. Namun lambat laun Sy berusaha bangun dari mimpi buruknya agar terhindar dari kondisi terpuruk dan stres, meskipun di saat saat tertentu masih merasa minder dengan kondisinya. Kemampuan mengelola stres yang baik mampu membuatnya berpikir positif meskipun dihadapkan dengan tekanan yang dialaminya dalam lingkungan sekitar dan mengembangkan diri secara optimal dengan cara melakukan aktivitas di sebuah yayasan ataupun LSM bersama dengan beberapa orang yang memiliki nasib yang sama. Sy tidak merasakan kesedihan berkepanjangan. Jalan hidupnya yang berat setelah menerima vonis bahwa dirinya positif mengidap HIV/AIDS membuatnya semakin kuat dalam menjalani berbagai masalah yang menimpanya. Pengalaman buruk telah berhasil membuatnya menjadi 
seorang remaja putri yang tangguh terlebih keadaan ekonomi keluarganya yang kurang baik membuatnya bersyukur dan bersabar dengan kondisi dirinya, yang semua orang pasti tidak akan pernah mau mengalaminya.

Luthans (Kurniawan \& Noviza, 2018) mengemukakan bahwa resiliensi dapat dikembangkan dengan meningkatkan aset yang dimiliki seseorang melalui pendidikan, pelatihan, dan dengan menjaga hubungan sosial serta secara umum meningkatkan kualitas sumber daya yang tersedia untuk dimiliki seseorang.

Berdasarkan latar belakang kasus yang diangkat, dapat disimpulkan bahwa pada dasarnya resiliensi yang dimiliki Subjek cukup mampu membuatnya bangkit dari mimpi buruk akibat vonis HIV/AIDS yang harus dideritanya. Subjek memiliki harapan untuk dapat memperbaiki kehidupannya menjadi lebih baik, karena Subjek memiliki hubungan sosial yang cukup baik dengan lingkungannya.

\section{Metode}

Subjek penelitian dipilih menggunakan cara purposive yaitu berdasarkan tujuan dari penelitian ini. Sugiyono (2007: 219) menjelaskan bahwa purposive merupakan teknik pengambilan sampel sumber data dengan pertimbangan tertentu. Pertimbangan tertentu yang dimaksudkan misalnya orang tersebut dianggap paling tahu tentang apa yang diharapkan atau mungkin dia sebagai penguasa sehingga akan memudahkan peneliti menjelajahi objek atau situasi sosial yang diteliti. Sy adalah seorang pelajar di SMP Terbuka di Semarang yang berusia 19 tahun. Sy terinfeksi HIV AIDS karena melakukan hubungan seksual akibat menjadi korban traficking Sekarang Sy tetap berkomunikasi dan bergaul dengan teman-temannya serta tidak mengurung diri. Sy meyakini bahwa meskipun dirinya terinfeksi HIV AIDS tetapi badannya masih bisa segar layaknya orang yang sehat tanpa penyakit. Sy juga menjadi salah satu aktivis di Yayasan Rumah Aira yang mewadahi ODHA. penelitian ini menggunakan metode studi kasus untuk mengungkap tentang gambaran resiliensi diri yang dimiliki dan factor yang melatarbelakangi hal tersebut. Selain itu, pemilihan metode ini didasarkan fakta bahwa tema dalam penelitian ini termasuk unik. Analisis data yang digunakan dalam penelitian ini menggunakan triangulasi sumber, dimana peneliti membandingkan data yang diperoleh dari subjek penelitian dan informan penelitian. 
Gambar 1. Kerangka Penelitian

$$
\text { Remaja yang terinfeksi HIV/AIDS }
$$

Resiliensi

Gambaran resiliensi

I have

I am

I can

\section{Hasil}

Dalam penelitian ini, semua data bersumber dari subjek penelitian dan dua key informan. Dalam penelitian ini yang menjadi key informan adalah relawan dan pimpinan Yayasan Rumah Aira. Nama subjek dan key informan yang digunakan peneliti merupakan nama inisial, hal ini dimaksudkan untuk menjaga kerahasiaan subjek penelitian dan key informan. Profil subjek penelitian adalah sbb:

$\begin{array}{ll}\text { Nama } & \text { Sy (inisial) } \\ \text { Jenis Kelamin } & \text { Perempuan } \\ \text { Usia } & 19 \text { tahun } \\ \text { Alamat } & \text { Purbalingga } \\ \text { Agama } & \text { Islam }\end{array}$

Sy terinfeksi HIV AIDS karena melakukan hubungan seks akibat menjadi korban traficking, melalui perkenalan di media sosial facebook dan tidak selalu menggunakan pengaman saat melakukan hubungan tersebut. Sy melakukan tes HIV karena terdapat beberapa gejala yang muncul di tubuh. Sy mengetahui bahwa dirinya positif HIV pada tahun 2016. Ketika mengetahui bahwa dirinya positif HIV, Sy mengatakan bahwa "kapan ya saya mati?." Selain data dari subjek penelitian juga diperoleh data dari key informan

Tabel 1. Profil Informan Kunci

\begin{tabular}{|c|c|c|c|}
\hline No & Keterangan & $\begin{array}{c}\text { Key Informan } \\
1\end{array}$ & $\begin{array}{c}\text { Key Informan } \\
2\end{array}$ \\
\hline 1 & Nama & LE (inisial) & SL (inisial) \\
\hline 2 & Jenis Kelamin & Perempuan & Laki-laki \\
\hline 3 & Usia & 52 tahun & 45 tahun \\
\hline 4 & Alamat & Semarang & Semarang \\
\hline 5 & Agama & Katolik & Islam \\
\hline 6 & Hubungan dengan subjek & Pimpinan Yayasan & Relawan \\
\hline
\end{tabular}


Dalam penelitian ini, peneliti membahas tentang resiliensi yang mengungkap latar belakang terinfeksi HIV AIDS dan tiga aspek resiliensi yaitu faktor I Have, I Am, dan I Can. Adapun hasil dari penelitian ini sebagai berikut:

Hasil Skala Resiliensi

Berdasarkan dari skala yang telah diujikan kepada subjek menunjukkan bahwa Sy berada pada kategori tinggi

\section{Diskusi}

Berdasarkan penelitian yang telah dilakukan peneliti terlihat bahwa latar belakang subjek terinfeksi HIV karena menjadi korban traficking dan melakukan hubungan seksual dengan para lelaki yang telah terinfeksi HIV AIDS Hal ini sejalan dengan teori yang dikemukakan oleh Darmono (2006: 80) bahwa penularan HIV dapat melalui hubungan kelamin tanpa pelindung, melalui tranfusi darah, penggunaan jarum suntik, dan dari ibu yang HIV positif ke bayi atau janin yang dikandungnya. Ditambahkan oleh Corliss \& Corliss (2006: 202) bahwa bentuk hubungan anal merupakan risiko tertinggi karena dapat menyebabkan sobeknya lapisan anal, dimana memungkinkan menginfeksi air mani yang kemudian masuk ke aliran darah. Respon Sy saat mengetahui bahwa dirinya terinfeksi HIV yaitu diam tanpa kata, tidak bisa menangis dan berteriak, seakan tidak percaya. Sy juga mengeluh dengan Tuhan dan melakukan hal untuk menyiapkan berbagai kenangan karena merasa akan meninggal. Hal tersebut karena Sy menganggap HIV AIDS adalah penyakit yang mematikan karena sampai sekarang belum ditemukan obatnya. Selain itu, Sy khawatir masih ada orang yang mau menerima dirinya atau tidak. Hal tersebut sejalan dengan teori yang diungkapkan oleh Burns, et al (2000: 411) bahwa ketika individu mengetahui bahwa positif HIV akan merasa seakan dunia sudah berakhir. Hal tersebut merupakan reaksi normal untuk merasa shock dan menyangka hasil tes yang positif tersebut. Selain itu, individu juga akan merasa marah dan putus asa serta menyalahkan diri sendiri dan orang lain.

Richardson (1998:109) juga mengungkapkan bahwa seseorang yang mengetahui bahwa dirinya menjadi seorang pengidap HIV positif akan menghadapi banyak masalah yang saling berhubungan dan terus dipikirkannya, salah satu masalahnya adalah kekuatiran dan depresi. "Kekuatiran yang dialami terasa lebih berat dan lebih dalam karena AIDS merupakan suatu penyakit yang menakutkan karena sampai saat ini penyembuhannya belum ditemukan" (Richardson, 1988: 113) dan "kebanyakan orang menjadi depresi saat mereka dinyatakan mengidap AIDS" (Richardson, 1988: 116). Namun Sy ingin menunjukkan bahwa ODHA sama seperti yang lain dengan cara mempercantik penampilan dan berusaha menjadi orang yang sukses, memandang dan memaknai hidupnya secara lebih positif karena mempunyai 
sikap resiliensi. Resiliensi merupakan kapasitas manusia untuk menghadapi, mengatasi, menjadi kuat, dan bahkan berubah karena pengalaman (Grotberg, 1999: 3). Individu yang resilien akan mampu untuk mengambil makna dari permasalahan yang ada dan mampu memperbaiki diri dari masalah yang dialami.

Aspek I Have

\section{a. Trusting relationship}

Kasih sayang dan kepercayaan di sebuah keluarga selalu ada untuk setiap anggotanya. Mempunyai hubungan yang dapat dipercaya dapat membuat individu merasa nyaman dan aman (Grotberg, 1999: 73). Selain itu, belajar untuk mempercayai orang lain dan diri sendiri merupakan bagian yang penting untuk mengatasi berbagai permasalahan yang timbul di kehidupan. Ketika masalah terjadi, individu tidak akan merasa kesepian dan sendirian karena percaya bahwa orang di sekitarnya akan tetap memberikan dukungan yang dibutuhkan. Hal tersebut dialami oleh subjek penelitian. Sy percaya bahwa keluarga dan teman-temannya tetap menerima irinya dengan kondisi sebagai ODHA sehingga berani membuka statusnya. Meskipun dengan kondisi sebagai ODHA, keluarga Sy tetap memberikan dukungan dan semangat. Selain mendapat dukungan dari keluarga, Sy juga mendapat dukungan dari sesama ODHA. Hal tersebut sejalan dengan teori Grotberg (1995: 25) bahwa individu dari semua usia membutuhkan kasih sayang yang tulus dan dukungan emosional dari orang tua serta orang-orang di sekitarnya (Grotberg, 1995: 15). Mempunyai hubungan dengan sesama ODHA memberikan pengaruh penting terhadap resiliensi yang dimiliki subjek. Dengan mengikuti kelompok dukungan membuat mereka mampu berbagi pengalaman dan bergaul dengan ODHA lainnya. Hal tersebut memberikan kekuatan tersendiri bagi ketiga subjek karena "kelompok dukungan merupakan tempat satu-satunya dimana ODHA dapat merasa nyaman, dapat keluar dari isolasi, terjaga kerahasiaannya, aman, dan terdukung" (Argyo Demartoto, 2010: 18). Kelompok dukungan juga dapat menjadi tempat dimana pendidikan dan penyebarluasan informasi mengenai HIV AIDS (Argyo Demartoto, 2010: 18).

\section{b. Structure and rules at home}

Setiap individu mempunyai aturan dan norma dalam kehidupannya. Sy mempunyai orang lain yang mengingatkan dirinya untuk melakukan berbagai hal baik. Hal ini sejalan dengan teori yang dikemukakan Grotberg (1995: 15) bahwa setiap individu harus mengikuti aturan yang ada di dalam kehidupan. Dijelaskan lebih lanjut bahwa individu mempunyai orang yang akan memberikan peringatan dan penjelasan tentang 
kesalahan yang dilakukan (Grotberg, 1995: 15). Dengan adanya aturan yang jelas, individu akan memahami apa yang seharusnya dilakukan dan tidak dilakukan (Grotberg, 1995: 15).

c. Role models

Orang di sekitar individu menunjukkan bagaimana melakukan sesuatu dan dalam hal ini akan mendorong individu untuk meniru mereka. Sy mempunyai sosok panutan yaitu ibunya sendiri karena melihat kegigihan, kesabaran, dan kerja keras ibunya dan mempunyai idola yaitu ibu panti karena beliau selalu memotivasi dan membuat dirinya banyak belajar. Kondisi ini sesuai dengan teori yang diungkapkan Grotberg (1999: 20) bahwa hal yang penting yaitu ketika individu meniru perilaku dari role models saat menghadapi adversitas. Hal tersebut dapat dijadikan sebagai bahan pelajaran bagi individu ketika menghadapi kesulitan.

\section{d. Encouragement to be autonomous}

Setiap individu diharapkan tidak selalu bergantung kepada orang lain tetapi mampu untuk melakukan berbagai hal secara mandiri. Sy mampu mandiri karena berasal dari dalam dirinya sendiri. Hal ini sejalan dengan teori yang diungkapkan Santrock (2002: 73) bahwa salah satu kriteria individu pada dewasa awal yaitu sudah mandiri secara ekonomi dan dalam membuat keputusan. Sy merasa dirinya mampu mandiri berasal dari didikan ibunya yang diajarkan untuk bekerja kera serta dari lingkungan keluarga yang sangat demokratis sehingga dia memperoleh banyak kesempatan untuk memutuskan berbagai jal sendiri. Hal ini sesuai dengan teori yang diungkapkan Grotberg (1995:16) bahwa individu didorong untuk menjadi otonom yaitu berusaha untuk melakukan sesuatu dengan sendiri dan berusaha mencari bantuan yang diperlukan. Apabila individu memperoleh kesempatan untuk melakukan berbagai hal dengan kemampuannya sendiri seperti mengambil keputusan, hal tersebut dapat membantu individu untuk menjadi otonom dan mampu bertindak secara inisiatif.

e. Access to helath, education, welfare, and security services

Individu yang mengidap HIV AIDS sangat membutuhkan berbagai layanan khususnya layanan kesehatan. Akan tetapi, ketiga subjek pernah mengalami diskriminasi pelayanan kesehatan di rumah sakit. Menurut Grotberg (1999: 73), individu akan merasa aman ketika mengetahui bahwa mempunyai berbagai layanan yang dapat digunakan ketika dibutuhkan. Berada di lingkungan yang aman sangat penting untuk mendorong resiliensi individu. Meskipun demikian, mereka tetap memperoleh berbagai layanan yang lain dengan sangat baik. Sy memperoleh akses obat dengan mudah dan saat ini dirinya tidak pernah mengalami diskriminasi. Selain itu, dalam aspek pendidikan dan keamanan, Sy juga memperoleh pelayanan yang baik. Hal tersebut menunjukkan bahwa salah satu masalah pengidap HIV positif adalah isolasi. Penderita HIV/AIDS sering kali dikucilkan 
oleh masyarakat (Richardson, 1988: 109). Hal ini karena salahnya info yang beredar mengenai AIDS dan penularannya sehingga membuat masyarakat takut dan was-was.

\section{Faktor I Am}

\section{a. Lovable and my temperament is appealing}

Sebagai makhluk sosial, setiap individu tidak bisa hidup tanpa orang lain. Oleh karena itu, mereka sebaiknya menjalin hubungan sosial dengan baik. Untuk menjalin hubungan tersebut, individu berusaha bersikap baik karena mereka akan diperhatikan apabila orang lain menyanyangi dan menyukainya (Grotberg, 1995: 16). Sy tetap mendapatkan berbagai bentuk perhatian dan dukungan baik dari keluarga maupun teman meskipun sudah mengetahui status kesehatannya sebagai ODHA. Sy disukai oleh orang lain karena sifatnya yang ceria, ramah, mudah bergaul, berjiwa sosial tinggi dan menyukai lingkungan baru serta selalu berpikir positif, supel, humoris, baik, dan ramah meskipun terkadang emosional. Hal ini sejalan dengan teori yang diungkapkan Grotberg (1999: 74) bahwa orang-orang akan lebih bersedia untuk menerima dan membantu individu ketika mereka melihat individu tersebut sebagai orang yang dicintainya.

\section{b. Loving, empathic, and altruistic}

Individu menyayangi orang lain dan mengekspresikannya dengan berbagai cara (Grotberg, 1995: 16). Sy sangat mudah mengungkapkan rasa sayangnya secara lisan. Ketika orang di sekitar terkena masalah, Sy berusaha untuk membantu tetapi tidak memaksa. Sy mudah paham dengan suasana hati orang lain sehingga ketika temannya ada masalah, sikap yang ditunjukkan tergantung situasi yang ada apakah temannya mau diajak bercerita atau tidak. Sy juga peduli dengan temannya ketika sedang ada masalah. Dirinya sering menjadi tempat bercerita oleh temannya. Ketika temannya ada masalah, dia mengajak temannya bercerita. Hal ini sejalan dengan teori yang diungkapkan oleh Grotberg (1995: 16) bahwa individu dapat merasakan ketidaknyamanan dan penderitaan orang lain dan ingin melakukan sesuatu untuk menghentikan atau membagi penderitaan tersebut atau memberikan kenyamanan. Kepedulian subjek juga dapat terlihat dari perilaku yang berusaha tidak menularkan HIV AIDS ke orang lain, karena Sy menganggap bahwa menjadi ODHA tidak mudah serta tidak mau generasi muda yang akan datang banyak terinfeksi HIV AIDS.

c. Autonomous and responsible

Individu dapat melakukan sesuatu dengan kemampuannya sendiri dan menerima konsekuensi dari tindakannya (Grotberg, 1995: 17). Individu yang 
resilien akan mampu untuk bertanggung jawab dengan apa yang telah dilakukan. Sy termasuk orang yang mandiri serta menerima konsekuensi sebagai ODHA dengan meminum obat secara rutin tanpa meminta bantuan orang lain. Sebagai seorang individu yang mempunyai berbagai peran dan tanggung jawab, subjek merupakan orang yang sudah memahami dan memenuhi kewajibannya sesuai dengan peran yang ada meskipun belum terlalu maksimal.

\section{d. Proud of myself}

Sy merasa bangga dengan kondisi sebagai ODHA tetapi masih bisa melakukan berbagai hal seperti individu lain yang sehat. Selain itu, dirinya menjadi contoh untuk ODHA lainnya terutama bagi remaja. Subjek mempunyai kebanggaan sendiri terhadap dirinya, hal ini sejalan dengan teori yang dikemukakan Grotberg (1995: 17) bahwa individu mengetahui bahwa dirinya merupakan orang yang penting dan bangga terhadap dirinya atas apa yang sudah dilakukan dan dicapai. Dengan kondisi sebagai ODHA, mereka tetap percaya terhadap kemampuan diri sendiri dan mengahargai dirinya dengan positif. Ketika individu mengalami masalah dalam hidupnya, kepercayaan dan harga diri membantu untuk dapat bertahan dan mengatasi masalah tersebut (Grotberg, 1995: 17).

\section{e. Filled with hope, faith, and trust}

Individu mempunyai kepercayaan bahwa sesuatu hal akan berjalan dengan baik dan mempunyai masa depan yang bagus (Grotberg, 1999: 74). Untuk mencapai hal tersebut, individu harus melakukan tanggung jawabnya dengan baik. Hal tersebut dialami oleh subjek. Sy mempunyai keyakinan akan tetap sehat meskipun menderita HIV AIDS. Selain itu, juga mempunyai berbagai harapan yang diyakini dapat diwujudkannya. Sy sudah mampu berpikir apa yang seharusnya dilakukan dan tidak dilakukan dengan belajar dari pengalaman yang telah dilalui. Hal ini sejalan dengan teori yang dikemukakan Grotberg (1999: 74) bahwa individu mengetahui apa yang benar dan apa yang salah karena mampu berpikir lebih kritis. Terkait harapan hidup kedepannya, Sy berharap bahwa ODHA tidak mengalami perlakukan diskriminasi lagi dan pengetahuan masyarakat mengenai ODHA tidak salah sehingga tidak merasa takut terhadap ODHA. Usaha yang Sy lakukan untuk mencapai hal tersebut dengan melakukan testimoni, penyuluhan, dan berbagi informasi. Sy merasa percaya dan optimis tentang masa depan kehidupannya. Selain itu, juga mempunyai berbagai harapan yang ingin dicapai. Kepercayaan, 
optimis, dan harapan merupakan faktor yang sangat dibutuhkan dalam menumbuhkan resiliensi karena risiko yang terjadi beriringan dengan meningkatnya kemandirian, motivasi diri, dan tanggung jawab terhadap keputusan yang ada (Grotberg, 1999: 128).

\section{Faktor I Can}

\section{a. Communicate}

Subjek mampu mengungkapkan apa yang dirasakan dan dipikirkan kepada orang lain. Hal ini sejalan dengan teori yang dikemukakan Grotberg (1995: 17) bahwa individu mampu untuk mengekspresikan pikiran dan perasaannya kepada orang lain. Sy mengungkapkan langsung ke orang yang bersangkutan apabila tidak bisa bertemu dengan orang tersebut maka dia mengklarifikasi melalui whats up. Hal ini sejalan dengan teori yang diungkapkan Grotberg (1995: 17) bahwa individu mampu menerima perbedaan yang ada dan memahami akibat yang akan terjadi ketika berkomunikasi dengan orang lain.

b. Problem solve

Setiap individu mempunyai cara masing-masing untuk menyelesaikan masalahnya. Sy meminta bantuan kepada orang lain ketika membutuhkan berbagai masukan dari orang lain. Hal ini sejalan dengan teori yang dikemukakan Grotberg (1995: 17) bahwa individu dapat menilai suatu masalah secara alami, mengetahui apa yang dibutuhkan untuk memecahkan masalah, dan bantuan apa yang diperlukan dari orang lain. Dalam memilih cara penyelesaian masalah juga dipengaruhi oleh kepribadian subjek. Sy adalah orang yang terbuka dan mudah akrab dengan orang lain sehingga ketika ada masalah dirinya memilih untuk bercerita dengan orang lain.

c. Manage my feeling and impulses

Ketika marah Sy akan bicara langsung ke orang yang bersangkutan dengan mengklarifikasi ke orang yang bersangkutan dengan cara yang halus. Hal ini sejalan dengan teori yang diungkapkan Grotberg (1995:18) bahwa individu mampu mengenali perasaan, dan berbagai jenis emosi, serta mengeskpresikannya ke dalam kata-kata ataupun perilaku namun tidak menggunakan kekerasan.

d. Gauge the temperament of myself and others

Sebagai seorang individu diharapkan sudah mampu memahami 
dirinya secara menyeluruh. Sy bukan tipe orang pendendam dan mampu mengontrol emosinya

e. Seek trusting relationship

Individu dapat menemukan seseorang seperti orang tua, saudara, orang dewasa lainnya, atau teman sebaya untuk meminta bantuan, membagi perasaan dan perhatian, untuk mencari cara untuk mengatasi masalah personal dan interpersonal, atau untuk mendiskusikan masalah di dalam keluarga (Grotberg, 1995: 18). Sy meminta bantuan ketika membutuhkan masukan mengenai masalahnya.Dengan mencari bantuan, individu akan memperoleh berbagai informasi, ide, perasaan, dan menemukan kenyamanan yang dapat membantu dalam menghadapi kesulitan. Sy mengungkapkan mempunyai teman dekat. Hal yang membuat Sy dekat dengan orang lain yaitu dengan saling cerita, berbagi masalah, dan pergi bersama.

Infeksi HIV AIDS akan menyebabkan perubahan yang dialami oleh ODHA seperti perilaku dan perasaan. Dinamika ODHA dari sebelum dan sesudah menerima keadaan dirinya sebagai ODHA akan ada perbedaan setiap waktunya. Sy mempunyai berbagai permasalahan yang berat. Di usia yang masih muda, harus keluar dari sekolah dan menjadi korban traficking, serta harus melakukan hubungan seks yang tidak dia kehendaki. Saat mengetahui positif HIV, Sy hanya bisa diam tanpa kata, tidak bisa menangis dan berteriak, seakan tidak percaya. Pada saat itu Sya khawatir a pakah akan ada orang yang masih mau menerima dirinya atau tidak. Sy mempunyai orang-orang terdekat yang tetap memberikan perhatian dan semangat meskipun sudah mengetahui kondisi kesehatannya.

Perhatian dan dukungan yang diberikan orang-orang di sekitar Sy membuat dirinya merasa aman dan nyaman. Sy menjadi lebih kuat karena melihat bahwa orang terdekatnya selalu ada untuk dirinya.Saat dibawa oleh Dinas Sosial ke Yayasan Rumah Aira, yang khusus mewadahi ODHA, hal tersebut membuat dirinya belajar dari pengalaman ODHA lainnya sehingga membuat dirinya semakin kuat karena merasa tidak sendirian. Selain itu, Sy juga mendapat layanan kesehatan, pendidikan, dan keamanan dengan baik. Melihat berbagai perhatian dan dukungan yang diterima Sy menunjukkan bahwa dirinya disayangi oleh orang lain. Sy disayangi oleh orang lain karena mempunyai sifat yang ramah, ceria, mudah bergaul, berjiwa sosial tinggi dan menyukai lingkungan baru. Sy juga mampu menunjukkan rasa sayangnya kepada orang lain, dengan ikut menjaga dan merawat adik adiknya di yayasan. Selain itu, Sy adalah orang yang peduli dengan orang lain dan menjaga supaya tidak menularkan HIV AIDS kepada 
orang lain. Akibat sifat baik yang dimiliki Sy membuat orang lain lebih bersedia untuk membantu dirinya karena menganggap Sy sebagai orang yang disayangi.

Sekarang Sy menjadi salah satu aktivis di Yayasan yang khusus mewadahi ODHA. Sy menjadi pendukung sebaya untuk sesama ODHA. Meskipun dengan kondisi sebagai ODHA, Sy bangga karena dapat membantu ODHA lain dan ekonomi keluargnya. Hal tersebut membuat penilaian terhadap dirinya menjadi lebih positif. Ketika mengalami masalah, kepercayaan dan harga diri dapat membantu Sy bertahan dan mengatasi masalah yang ada. Harapan dan keyakinan yang dimiliki Sy semakin meningkatkan semangat untuk bangkit dari keterpurukan karena percaya bahwa sesuatu hal akan berjalan dengan baik dan mempunyai masa depan yang bagus.

\section{Simpulan}

Berdasarkan dari hasil penelitian yang dilakukan dapat disimpulkan gambaran resiliensi yang dimiliki subjek dapat dilihat dari aspek I Have, I Am, dan I Can.

I Have yang meliputi mendapat dukungan dan perhatian dari orang lain, Subjek lebih mementingkan kesenangan dan kenyamanan, mempunyai panutan, mempunyai dorongan untuk mandiri, mendapat layanan pendidikan dan keamanan dengan baik. I Am subjek mempunyai sifat yang menarik dan mempunyai perasaan disayangi orang lain, mampu mengungkapkan rasa sayang melalui perbuatan, peduli dengan orang lain, menjaga supaya tidak menularkan HIV AIDS ke orang lain.S ubjek mampu mandiri dan bertanggung jawab meskipun belum maksimal, mereka yakin akan tetap sehat, mempunyai harapan hidup yang bagus dan yakin mampu mewujudkannya. I Can, subjek mampu mengungkapkan apa yang dirasakan dan pikirkan dengan cara masing-masing, mampu menyelesaikan masalah yang dihadapi, mampu mencari bantuan yang dibutuhkan dan menjalin hubungan baik dengan orang lain. Penyebab subjek terinfeksi HIV AIDS akibat hubungan seks yang dilakukan sebagai bagian dari korban traficking.

\section{Saran}

Bagi Subjek penelitian, agar dapat mempertahankan resilisensi yang dimiliki, sehingga menjadi lebih bermanfaat bagi orang lain dan dapat membangun image positif di masyarakat bahwa penderita HIV/ AIDS juga dapat memiliki kontribusi dalam masyarakat.

Bagi masyarakat yang masih memandang penderita HIV/AIDS harus dijauhi, dengan adanya penelitian ini dapat lebih terbuka wawasannya, bahwa bukan orangnya yang harus dijauhi, tetapi penyakitnya yang dijauhi. Penderita HIV/AIDS juga memiliki hak yang sama untuk hidup dan berkarya bagi masyarakat. 
Azwar, S. 2003. Penyusunan Skala Psikologi. Yogyakarta: Pustaka Pelajar Offset

Calhoun, J.F. dan Acocella, J.R. 1995. Psikologi Tentang Penyesuaian dan Hubungan Kemanusiaan. New York : Mc Graw Hill

Chaplin, C.B. 1995. Kamus Lengkap Psikologi. (Terjemahan: Kartini Kartono).ed 1. cetakan ke-2. Jakarta: Grafindo Persada.

Davidoff. 1991. Psikologi Suatu Pengantar. Jilid 2. Alih Bahasa : Mari Jumiati.Jakarta : Erlangga

Gerungan, W.A. 1996. Psikologi Sosial. Bandung : PT Eresco

Herdiansyah, Haris. 2015. Metodologi Penelitian Kualitatif untuk Ilmu Psikologi. Jakarta : Salemba Humanika

Hurlock, E. 2004. Psikologi Perkembangan. Jakarta : Erlangga Press

Kementrian Kesehatan RI (2012) : MEDIAKOM Mengenal, Mencegah Pertumbuhan HIV-AIDS. Jakarta.

Komisi Penanggulangan AIDS (KPA), (2003) Strategi Nasional Penanggulangan AIDS, 20032007, Menkosesra, KPAN, Jakarta.

Kurniawan, Y., \& Noviza, N. (2018). Peningkatan Resiliensi pada Penyintas Kekerasan terhadap Perempuan Berbasis Terapi Kelompok Pendukung. Universitas Islam Negeri Walisongo, 2(2), 125-142. http://dx.doi.org/10.21580/pjpp.v2i2.1968

Sarafino. 1998. Health Psikologi : Biopsychosocial Interaction. USA : John Willey and sons

Smet, B. 1994, Psikologi Kesehatan. Jakarta : PT Grasindo 